\title{
GEODERMA
}

ELSEVIER

www.elsevier.nl/locate/geoderma

\section{Phosphate retention and extractability in soils of the humid zone in West Africa}

\author{
M.K. Abekoe ${ }^{\text {a }}$, K.L. Sahrawat ${ }^{\text {b,* }}$ \\ ${ }^{a}$ Department of Soil Science, University of Ghana, Legon, Accra, Ghana \\ ${ }^{\mathrm{b}}$ West Africa Rice Development Association (WARDA), 01 B.P. 2551, Bouaké 01, Ivory Coast
}

Received 23 February 2000; accepted 6 December 2000

\begin{abstract}
Phosphate adsorption and desorption studies provide insight for developing $\mathrm{P}$ management strategies. Very few studies have concentrated on $\mathrm{P}$ desorption which provides information on the reversibility of adsorbed $\mathrm{P}$. Phosphate adsorption and desorption studies were carried out on seven rice-growing soils from three countries in West Africa, with the objective of relating these processes to $\mathrm{P}$ management strategies for the soils. The standard $\mathrm{P}$ requirement (SPR) of soils, defined as the amount of $\mathrm{P}$ to be added to attain an equilibrium solution concentration of $0.2 \mathrm{mg} \mathrm{P}$ $1^{-1}$, varied from 42 to $175 \mathrm{mg} \mathrm{P} \mathrm{kg}^{-1}$. Out of the seven soils, four required low amounts and the other three needed relatively higher $\mathrm{P}$ applications. The extractability of the adsorbed $\mathrm{P}$ in

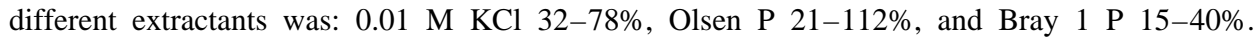
Differences in the amounts of $\mathrm{P}$ desorbed by the soils suggested that the critical $\mathrm{P}$ levels needed for $\mathrm{P}$ management must be different. Management options to increase $\mathrm{P}$ availability in the soils are suggested. (C) 2001 Elsevier Science B.V. All rights reserved.
\end{abstract}

Keywords: Phosphorus; Adsorption; Desorption; Extractability of P; Soils; Humid zone

\section{Introduction}

The rain-fed lowland and upland ecosystems in West Africa are very important for rice production. Approximately $40 \%$ of the lowland and about $70 \%$ of the upland rice is grown in the humid zone of West Africa. Phosphorus

\footnotetext{
${ }^{*}$ Corresponding author. Tel.: +225-31-63-45-14; fax: +225-31-63-47-14.

E-mail address: k.sahrawat@cgiar.org (K.L. Sahrawat).
} 
deficiency has been identified as one of the major limiting factors to crop production in highly weathered, low-activity, Ultisols and Oxisols (Sanchez and Salinas, 1981; Warren, 1992). Such soils are low in P and the applied P is made unavailable by reactions with iron oxides (Juo and Fox, 1977; Mokwunye et al., 1986).

It is important to understand the behaviour of phosphate, especially its adsorption and desorption by soils, to supplement the information already available on P response to direct and residual P (Sahrawat et al., 1995, 1997a), and calibration of soil and plant tests for developing $\mathrm{P}$ management strategies for rice-based production systems (Sahrawat et al., 1997b, 1998). While studies have been made on P adsorption of West African soils (Juo and Fox, 1977; Owusu-Bennoah and Acquaye, 1989; Owusu-Bennoah et al., 1997), little attention has been paid to desorption of the adsorbed $\mathrm{P}$ by acid soils used for crop cultivation in West Africa.

This study was undertaken to evaluate the phosphate adsorption-desorption characteristics of seven representative rice-growing soils in West Africa and to relate these with soil properties that can serve as indices for routine characterization of phosphate adsorption capacity of the soils.

\section{Materials and methods}

\subsection{Soils}

Surface $(0-0.15 \mathrm{~m})$ samples of seven highly weathered soils were selected (Narteh and Sahrawat, 1999) from typical rice-growing areas in Nigeria, Ghana and Côte d'Ivoire (Table 1). Soils 1, 2, 3, 4 and 5 were sampled from the lowlands. Soils 6 and 7 were from uplands and were included for comparison. The soils were air-dried and ground to pass through a 2-mm screen.

Table 1

List of the soils used

\begin{tabular}{llll}
\hline Soil no. & Location & $\begin{array}{l}\text { Classification } \\
\text { FAO (1988) }\end{array}$ & Vegetation \\
\hline 1 & Edozhighi, Nigeria $\left(9^{\circ} 06^{\prime} \mathrm{N}, 5^{\circ} 59^{\prime} \mathrm{E}\right)$ & Dystric Gleysol & Derived savanna \\
2 & Ifaki-Ekiti, Nigeria $\left(7^{\circ} 14^{\prime} \mathrm{N}, 5^{\circ} 08^{\prime} \mathrm{E}\right)$ & Eutric Gleysol & Secondary forest \\
3 & Itokin, Nigeria $\left(6^{\circ} 36^{\prime} \mathrm{N}, 3^{\circ} 32^{\prime} \mathrm{E}\right)$ & Dystric Gleysol & Secondary forest \\
4 & Fumesua, Ghana $\left(6^{\circ} 54^{\prime} \mathrm{N}, 1^{\circ} 35^{\prime} \mathrm{W}\right)$ & Gleyic Arenosol & Secondary forest \\
5 & Kikam, Ghana $\left(4^{\circ} 53^{\prime} \mathrm{N}, 2^{\circ} 14^{\prime} \mathrm{W}\right)$ & Dystric Gleysol & Secondary forest \\
6 & Bouaké, Côte d'Ivoire $\left(7^{\circ} 42^{\prime} \mathrm{N}, 5^{\circ} 00^{\prime} \mathrm{W}\right)$ & Eutric Leptosol & Forest-Savanna \\
& & & transition \\
7 & Man, Côte d'Ivoire $\left(7^{\circ} 31^{\prime} \mathrm{N}, 7^{\circ} 37^{\prime} \mathrm{W}\right)$ & Ferric Acrisol & Secondary forest \\
\hline
\end{tabular}




\subsection{Soil analysis}

Soil analysis was done as described in Narteh and Sahrawat (1999). Particle size distribution was determined by the pipette method. Soil $\mathrm{pH}$ was measured in water (1:2.5), $1 \mathrm{M} \mathrm{KCl} \mathrm{(1:2.5),} 1 \mathrm{M} \mathrm{NaF}$ (pH 8.0) (1:40, Bolland et al., 1996) and $0.5 \mathrm{M} \mathrm{NaHCO}_{3}(\mathrm{pH} 8.5)(1: 2.5)$. The rationale for determining soil $\mathrm{pH}$ in 1 $\mathrm{M} \mathrm{NaF}$ and $0.5 \mathrm{M} \mathrm{NaHCO}_{3}$ is to predict phosphate sorption capacity of soils from the measured $\mathrm{pH}$. Total $\mathrm{P}$ of the soils was determined by digestion with perchloric acid. Available $\mathrm{P}$ was determined using $0.03 \mathrm{~N} \mathrm{NH}_{4} \mathrm{~F}+0.025 \mathrm{~N} \mathrm{HCl}$ (Bray 1) at 1:7 soil/solution ratio (Olsen and Sommers, 1982). Dithionitecitrate-bicarbonate extractable $\mathrm{Fe}\left(\mathrm{Fe}_{\mathrm{d}}\right)$ and $\mathrm{Al}\left(\mathrm{Al}_{\mathrm{d}}\right)$ were determined as described by Mehra and Jackson (1960) and oxalate extractable $\mathrm{Fe}\left(\mathrm{Fe}_{\mathrm{o}}\right)$ and $\mathrm{Al}$ $\left(\mathrm{Al}_{\mathrm{o}}\right)$ as described by McKeague (1978). Iron and $\mathrm{Al}$ in the extracts were determined by atomic absorption spectrophotometry.

\subsection{Phosphorus adsorption}

Phosphorus adsorption data were obtained following Fox and Kamprath (1970). Soil samples ( $2 \mathrm{~g}$ ) were equilibrated in 50-ml centrifuge tubes with 20 $\mathrm{ml}$ of $0.01 \mathrm{M} \mathrm{KCl}$ containing $0-400 \mathrm{mg} \mathrm{P} \mathrm{kg}{ }^{-1}$ soil as $\mathrm{KH}_{2} \mathrm{PO}_{4}$. The weights for the tubes containing the $400 \mathrm{mg} \mathrm{P} \mathrm{kg} \mathrm{Pg}^{-1}$ were recorded for subsequent desorption studies. A few drops of toluene were added to suppress microbial activity during incubation and the soil samples were incubated at $25^{\circ} \mathrm{C}$ for 6 days. The suspensions were shaken for $30 \mathrm{~min}$, twice daily on a mechanical shaker. After equilibration, the samples were centrifuged for $10 \mathrm{~min}$ and filtered through Whatman no. 1 filter paper. The $\mathrm{P}$ content in the clear solution was determined by the molybdenum blue method (Olsen and Sommers, 1982). Since there were no significant differences between the duplicates, the average value of the duplicate analysis was used to calculate the amount of $\mathrm{P}$ in solution. The difference in the amount of $\mathrm{P}$ added and that recovered in solution was considered as $\mathrm{P}$ retained by the soil.

A linear form of the Langmuir equation $C / X=C / b+1 / k b$ was used to evaluate the adsorption data. In the equation, $C$ is equilibrium $\mathrm{P}$ concentration (mg $\left.\mathrm{P}^{-1}\right), X$ is the amount of $\mathrm{P}$ sorbed $\left(\mathrm{mg} \mathrm{P} \mathrm{kg}^{-1}\right), b$ is the Langmuir adsorption maximum, and $k$ is a constant related to the binding energy. The $b$ was determined from the slope of the plot of $C / X$ against $C$ and $k$ was calculated from the intercept. Phosphate adsorption buffer capacity (PBC) was estimated from the $\mathrm{P}$ adsorption curves as the slope of the regression equation relating $\mathrm{P}$ adsorbed to $\log \mathrm{P}$ concentration. The amount of $\mathrm{P}$ required by the soils to attain a concentration of $0.2 \mathrm{mg} \mathrm{P}^{-1}$ after 6 days (standard $\mathrm{P}$ requirement (SPR)) was extrapolated from a graph of $\mathrm{P}$ adsorbed against equilibrium $\mathrm{P}$ concentration. 


\subsection{Phosphorus release}

After separating the $\mathrm{P}$ in solution, samples to which $400 \mathrm{mg} \mathrm{P} \mathrm{kg}^{-1}$ soil was added were subjected to a desorption sequence to determine the $\mathrm{P}$ release. To correct for the entrained solution left in the tubes after filtration, the tubes were weighed and sufficient amount of $0.01 \mathrm{M} \mathrm{KCl}$ was added to bring the volume of solution back to $20 \mathrm{ml}$. The suspensions were then shaken for $2 \mathrm{~h}$ on a mechanical shaker (Tiessen et al., 1993), centrifuged and filtered through Whatman no. 1 filter paper. The $\mathrm{P}$ desorbed was determined as previously described. The desorption was conducted eight successive times and each time the released $\mathrm{P}$ was measured.

Another set of the soils held in centrifuge tubes was incubated for 1 week with $\mathrm{P}$ added at a rate of $40 \mathrm{mg} \mathrm{P} \mathrm{kg}^{-1}$. Phosphate desorption cycles were carried out successively for two times using Bray 1 and Olsen extractants. A blank without $\mathrm{P}$ but only the extractants added was included in the desorption experiment.

\section{Results and discussion}

\subsection{Soils}

The texture and some chemical characteristics of the soils are summarized in Table 2. The data on particle size distribution, total $\mathrm{P}$, Bray $1 \mathrm{P}$, organic $\mathrm{C}$ and DTPA extractable iron are from Narteh and Sahrawat (1999). Soil $\mathrm{pH}$ in various solutions and extractable $\mathrm{Fe}$ and $\mathrm{Al}$ fractions were determined in this study. Apart from soil 2, the soils are acid, low in organic $\mathrm{C}$ and available $\mathrm{P}$. The clay content was low to moderate. The $\mathrm{Fe}_{\mathrm{d}}$ values ranged from 1.8 to $28.6 \mathrm{~g} \mathrm{~kg}^{-1}$ and the $\mathrm{Fe}_{\mathrm{o}} / \mathrm{Fe}_{\mathrm{d}}$ ratio was $\geq 0.39$ except in two soils, indicating that most of the soils have a high percentage of low-crystalline Fe oxides capable of immobilising P. In soil 2 situated at the bottom of a toposequence, the clay and silt content amounted to $962 \mathrm{~g} \mathrm{~kg}^{-1}$. It is a redoximorphic soil with high $\mathrm{pH}$ due to reduction. In addition to its high $\mathrm{pH}$ value, the soil had high $\mathrm{Fe}_{\mathrm{d}}(28.6 \mathrm{~g}$ $\left.\mathrm{kg}^{-1}\right)$ and $\mathrm{Fe}_{\mathrm{o}}\left(11.4 \mathrm{~g} \mathrm{~kg}^{-1}\right)$ values. As was expected from its high $\mathrm{pH}$, the soil also had the highest $\mathrm{Ca}$ content $\left(14.8 \mathrm{cmol}(+) \mathrm{kg}^{-1}\right)$ among the studied soils and a CEC of $30 \mathrm{cmol}(+) \mathrm{kg}^{-1}$ (Narteh and Sahrawat, 1999).

\subsection{Phosphorus adsorption}

The $\mathrm{P}$ adsorption data for all the soils fitted well to the Langmuir equation $\left(r^{2}>0.972\right)$. The $\mathrm{P}$ adsorbed against equilibrium $\mathrm{P}$ concentration graphs for soils 2 and 3 failed to show a maximum (equivalent to a plateau) at the highest 
Table 2

Texture and chemical characteristics of the soils

\begin{tabular}{|c|c|c|c|c|c|c|c|c|c|c|c|c|c|c|}
\hline \multirow[t]{2}{*}{ Soil no. } & \multicolumn{4}{|l|}{$\mathrm{pH}$} & \multirow{2}{*}{$\begin{array}{l}\text { Sand } \\
\left(\mathrm{g} \mathrm{kg}^{-1}\right)\end{array}$} & \multirow{2}{*}{$\begin{array}{l}\text { Silt } \\
\left(\mathrm{g} \mathrm{kg}^{-1}\right)\end{array}$} & \multirow{2}{*}{$\begin{array}{l}\text { Clay } \\
\left(\mathrm{g} \mathrm{kg}^{-1}\right)\end{array}$} & \multirow{2}{*}{$\begin{array}{l}\text { Total P } \\
\left(\mathrm{mg} \mathrm{kg}^{-1}\right)\end{array}$} & \multirow{2}{*}{$\begin{array}{l}\text { Bray 1 } \\
\left(\mathrm{mg} \mathrm{kg}^{-1}\right)\end{array}$} & \multirow{2}{*}{$\begin{array}{l}\text { Org. C } \\
\left(\mathrm{g} \mathrm{kg}^{-1}\right)\end{array}$} & \multirow{2}{*}{$\begin{array}{l}\mathrm{Fe}-\mathrm{DTPA} \\
\left(\mathrm{g} \mathrm{kg}^{-1}\right)\end{array}$} & \multirow{2}{*}{$\begin{array}{l}\mathrm{Fe}_{\mathrm{d}} \\
\left(\mathrm{g} \mathrm{kg}^{-1}\right)\end{array}$} & \multirow{2}{*}{$\begin{array}{l}\mathrm{Fe}_{\mathrm{o}} \\
\left(\mathrm{g} \mathrm{kg}^{-1}\right)\end{array}$} & \multirow[t]{2}{*}{$\mathrm{Fe}_{\mathrm{o}} / \mathrm{Fe}_{\mathrm{d}}$} \\
\hline & $\mathrm{H}_{2} \mathrm{O}$ & $\mathrm{KCl}$ & $\mathrm{NaF}$ & $\mathrm{NaHCO}_{3}$ & & & & & & & & & & \\
\hline 1 & 4.3 & 3.6 & 8.8 & 8.8 & 333 & 504 & 163 & 162 & 8 & 7.8 & 0.34 & 4.25 & 3.18 & 0.75 \\
\hline 2 & 7.7 & 6.9 & 10.0 & 8.6 & 38 & 452 & 510 & 1125 & 3 & 46.0 & 0.18 & 28.7 & 11.4 & 0.40 \\
\hline 3 & 4.9 & 3.9 & 9.8 & 8.7 & 419 & 366 & 215 & 163 & 8 & 9.8 & 0.18 & 8.80 & 3.40 & 0.39 \\
\hline 4 & 5.4 & 4.2 & 8.8 & 8.8 & 813 & 142 & 45 & 89 & 12 & 8.8 & 0.11 & 3.88 & 3.56 & 0.92 \\
\hline 5 & 5.1 & 4.0 & 9.0 & 8.7 & 160 & 490 & 350 & 448 & 5 & 35.2 & 0.26 & 1.85 & 1.10 & 0.59 \\
\hline 6 & 6.3 & 5.0 & 8.7 & 8.8 & 684 & 228 & 88 & 211 & 10 & 7.4 & 0.02 & 9.63 & 0.93 & 0.10 \\
\hline 7 & 5.0 & 4.1 & 9.3 & 8.6 & 408 & 294 & 298 & 234 & 6 & 15.6 & 0.17 & 9.53 & 1.53 & 0.16 \\
\hline
\end{tabular}

Source: Partly from Narteh and Sahrawat (1999). 


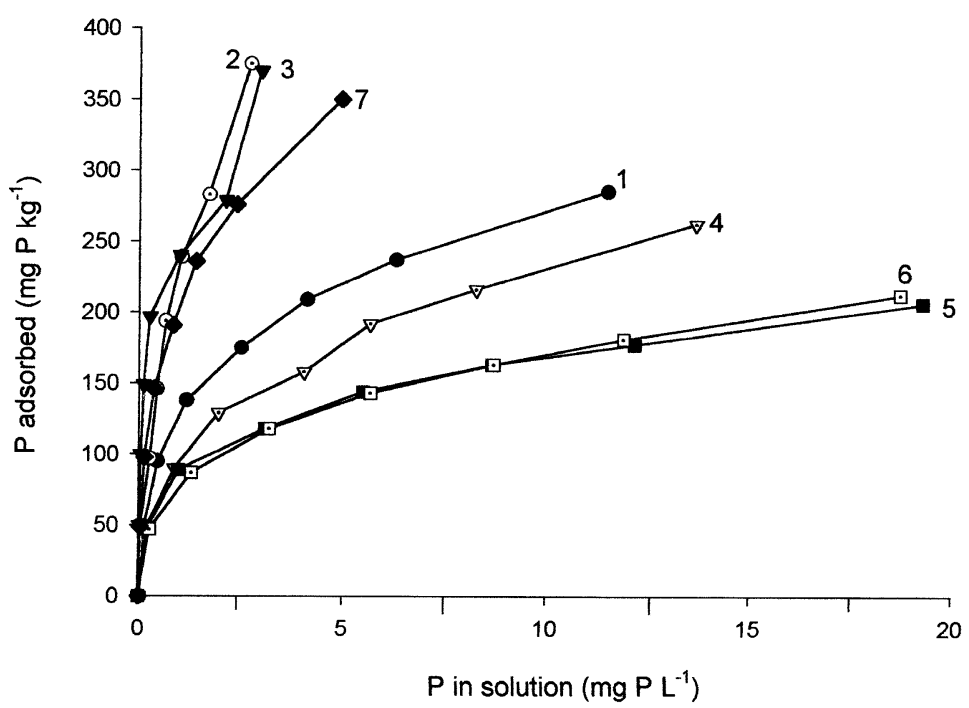

Fig. 1. Phosphorus sorption curves showing the relationship between $\mathrm{P}$ adsorbed and $\mathrm{P}$ in solution for seven West African soils (1 to 7).

equilibrium $\mathrm{P}$ concentration and therefore the calculated Langmuir $\mathrm{b}$ were greater than $400 \mathrm{mg} \mathrm{P} \mathrm{kg}^{-1}$ (Fig. 1 and Table 3). The Langmuir $b$ was highest for soil 3 and lowest for soil 14 and was significantly related to $\mathrm{Fe}_{\mathrm{d}}$ and $\mathrm{Fe}_{\mathrm{o}}$. The simple linear correlation coefficients between Langmuir $\mathrm{P}$ sorption maximum, percentage of $\mathrm{P}$ recovery after eight desorptions and soil characteristics are shown in Table 4. The Langmuir $\mathrm{P}$ sorption maximum was significantly related to $\mathrm{Fe}_{\mathrm{d}}, \mathrm{Fe}_{\mathrm{o}}, \mathrm{Al}_{\mathrm{d}}$ and to $\mathrm{pH}$ determined in $1 \mathrm{M} \mathrm{NaF}$. According to Owusu-Bennoah and Acquaye (1989) Al is important for P sorption in many acid soil of Ghana. There was no significant relationship between $\mathrm{P}$ sorption and $\mathrm{pH}$ in water or $\mathrm{KCl}$, clay or organic $\mathrm{C}$.

Table 3

Phosphorus sorption parameters of the soils

\begin{tabular}{|c|c|c|c|c|}
\hline \multirow[t]{2}{*}{ Soil no. } & \multicolumn{2}{|l|}{ Langmuir } & \multirow[t]{2}{*}{$\operatorname{PBC}\left(1 \mathrm{~kg}^{-1}\right)$} & \multirow{2}{*}{$\begin{array}{l}\text { Amount of } \mathrm{P} \text { adsorbed } \\
\left(\mathrm{mg} \mathrm{kg}^{-1}\right) \text { at } 0.2 \mathrm{mg} \mathrm{P}^{-1} \\
\text { of solution (SPR) }\end{array}$} \\
\hline & $\begin{array}{l}\mathrm{P} \operatorname{maximum}(b) \\
\left(\mathrm{mg} \mathrm{P} \mathrm{kg}^{-1}\right)\end{array}$ & $\begin{array}{l}\text { Affinity index }(k) \\
\left(1 \mathrm{mg}^{-1}\right)\end{array}$ & & \\
\hline 1 & 296 & 0.97 & 18.5 & 50 \\
\hline 2 & 567 & 1.72 & 114 & 80 \\
\hline 3 & 449 & 4.86 & 85.4 & 175 \\
\hline 4 & 277 & 0.56 & 14.7 & 45 \\
\hline 5 & 210 & 0.63 & 7.36 & 44 \\
\hline 6 & 207 & 0.67 & 8.10 & 42 \\
\hline 7 & 369 & 1.96 & 54.5 & 115 \\
\hline
\end{tabular}


Table 4

Correlation coefficients (r) between Langmuir P sorption maximum, desorption and selected soil characteristics of the seven soils

\begin{tabular}{llc}
\hline Soil property & Langmuir P maximum & $\begin{array}{l}\text { Recovery }(\%) \text { of added } \\
\text { P in eight desorptions }\end{array}$ \\
\hline $\mathrm{pH}, \mathrm{H}_{2} \mathrm{O}$ & 0.473 & 0.415 \\
$\mathrm{pH}, \mathrm{KCl}$ & 0.586 & 0.295 \\
$\mathrm{pH}, \mathrm{NaF}$ & $0.935^{* *}$ & -0.286 \\
$\mathrm{pH}, \mathrm{NaHCO}$ & 0.349 \\
$\mathrm{Clay}$ & 0.694 & -0.440 \\
Organic C & 0.640 & -0.367 \\
$\mathrm{DTPA}-\mathrm{Fe}$ & 0.454 & $-0.855^{*}$ \\
$\mathrm{Fe}_{\mathrm{d}}$ & 0.075 & 0.166 \\
$\mathrm{Fe}_{\mathrm{o}}$ & $0.819^{*}$ & -0.140 \\
$\mathrm{Al}_{\mathrm{d}}$ & $0.832^{*}$ & 0.189 \\
$\mathrm{Al}_{\mathrm{o}}$ & $0.847^{*}$ & -0.147 \\
\hline
\end{tabular}

${ }^{*}$ Significant at $5 \%$ levels, respectively.

* * Significant at $1 \%$ levels, respectively.

The following multiple regression equations are the regressions for $\mathrm{Fe}_{\mathrm{d}}$ and $\mathrm{Fe}_{\mathrm{o}}$ separately although it should be noted that $\mathrm{Fe}_{\mathrm{d}}$ may contain $\mathrm{Fe}_{\mathrm{o}}$ :

$$
\begin{aligned}
& b=221+5.68 \mathrm{Fe}_{\mathrm{d}}+18.03 \mathrm{Fe}_{\mathrm{o}} \quad r^{2}=0.728 \\
& b=-102+61.4 \mathrm{pH}+1.31 \text { clay }-11.3 \mathrm{OC} \quad r^{2}=0.667
\end{aligned}
$$

and indicate that iron oxides accounted for $73 \%$ of the variability in $\mathrm{P}$ adsorption whereas $\mathrm{pH}$, clay and organic $\mathrm{C}$ together accounted for only $67 \%$. The amounts of $\mathrm{P}$ required to attain an equilibrium concentration of $0.2 \mathrm{mg}^{-1}$ (SPR) varied between 42 and $175 \mathrm{mg} \mathrm{kg}^{1}{ }^{1}$ (Table 3). The SPR of soils 2, 3 and 7 were higher than reported for some soils in West Africa (Adetunji, 1997; Mokwunye et al., 1986), but the second group of soils had SPR within the range for most West African soils. As expected, the soils with relatively high SPR also had high Langmuir $\mathrm{k}$, consequently there was a close relationship between them (Fig. 2).

The P buffering capacity, PBC (Holford, 1979), was highest for soils 2, 3 and 7 (Table 3).

\subsection{Phosphorus desorption}

The soils retained between 206 (soil 6) and $375 \mathrm{mg} \mathrm{P} \mathrm{kg}^{-1}$ soil (soil 2) (Fig. 3). The $\mathrm{P}$ released during eight successive 2-h extractions with $0.01 \mathrm{M} \mathrm{KCl}$ varied from $68 \mathrm{mg} \mathrm{kg}^{-1}(32 \%)$ in soil 5 to $160 \mathrm{mg} \mathrm{kg}^{-1}(78 \%)$ in soil 6 . This suggests that when $\mathrm{P}$ is applied to soil 6 , it is more easily available to the rice 


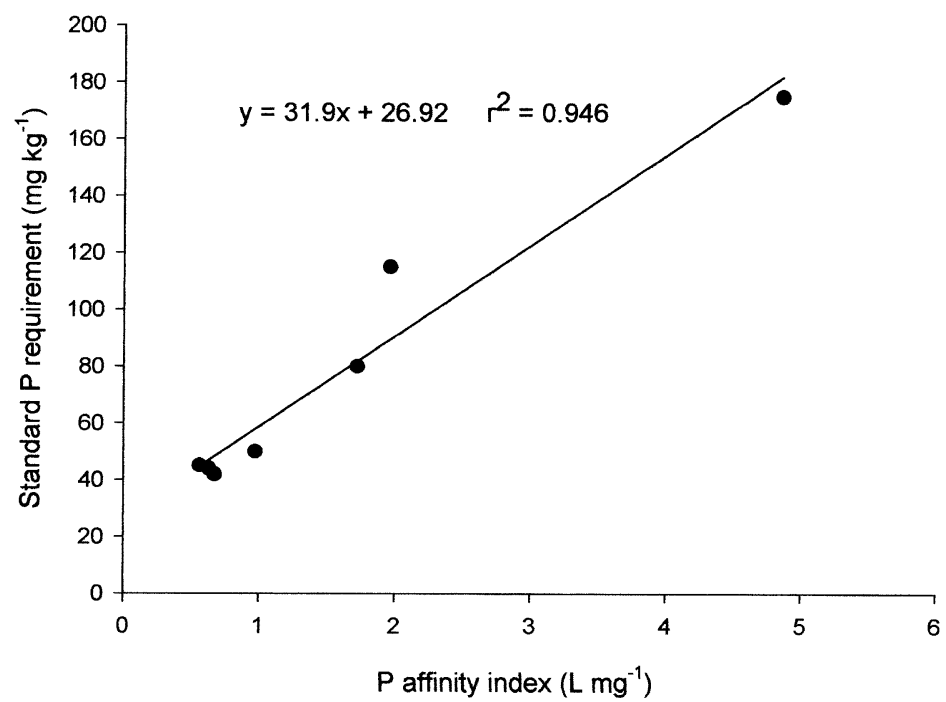

Fig. 2. Relationship between Standard Phosphorus Requirement (SPR) and the Langmuir affinity index $(k)$ for seven West African soils.

crop than that of soil 5. During extraction, the amount of $\mathrm{P}$ remaining retained at a given equilibrium $\mathrm{P}$ concentration in solution was higher than during adsorption in soils 1, 4 and 5, indicating a low extractability of the bound $\mathrm{P}$ in these soils. Because these soils have low PBC or are poorly buffered, hysteresis was pronounced in them (Fig. 3 and Table 3). The opposite was true for soils 2 and 3 , in which more $\mathrm{P}$ was in solution during desorption than during adsorption. This is consistent with the proposition that these soils have high PBC and can maintain solution concentration for a longer time than in the rest of the soils. The results of the desorption study, therefore, suggest that the critical limit for $\mathrm{P}$ in soil solution in the studied soils may be different and $\mathrm{P}$ management strategies for rice in these West African soils will depend on the soil type.

Except for soil 2, the greatest release of $\mathrm{P}$ from each sample into $0.01 \mathrm{M} \mathrm{KCl}$ was at the first step and decreased after the initial extractions, in conformity with the results of Dev et al. (1990). Despite low release, at the end of the eight successive 2-h extractions with $\mathrm{KCl}$, the solution $\mathrm{P}$ maintained by all soils

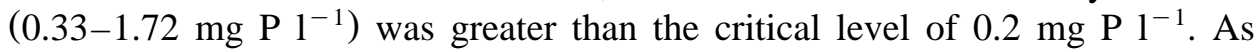
judged from its extractability in $\mathrm{KCl}$, these soils can well support rice production. For example, in a field study on $\mathrm{P}$ response of upland rice on soil 7, it was shown that soil solution $\mathrm{P}$ concentration of $0.05 \mathrm{mg} \mathrm{l}^{-1}$ (equivalent to about 60 $\mathrm{kg} \mathrm{P} \mathrm{ha}{ }^{-1}$ ) was adequate for optimum yield (Sahrawat et al., 1995). According to this study, the soil factor that controlled release of the added $\mathrm{P}$ in the seven soils studied was DTPA-extractable Fe (Table 4), which was negatively and significantly correlated with the percent $\mathrm{P}$ recovery $(r=-0.855)$. 
After 1 week of incubation of the soils with $40 \mathrm{mg} \mathrm{P} \mathrm{kg}^{-1}$, the percentage of Olsen-P was consistently greater than Bray 1-P in all soils (Table 5) and was positively related to soil $\mathrm{pH}\left(r=0.766^{*}\right)$. This was evident in soil $2(\mathrm{pH} 7.7)$, in which $\mathrm{P}$ released was $>40 \mathrm{mg} \mathrm{P} \mathrm{kg}^{-1}$ and thus some native $\mathrm{P}$ was also
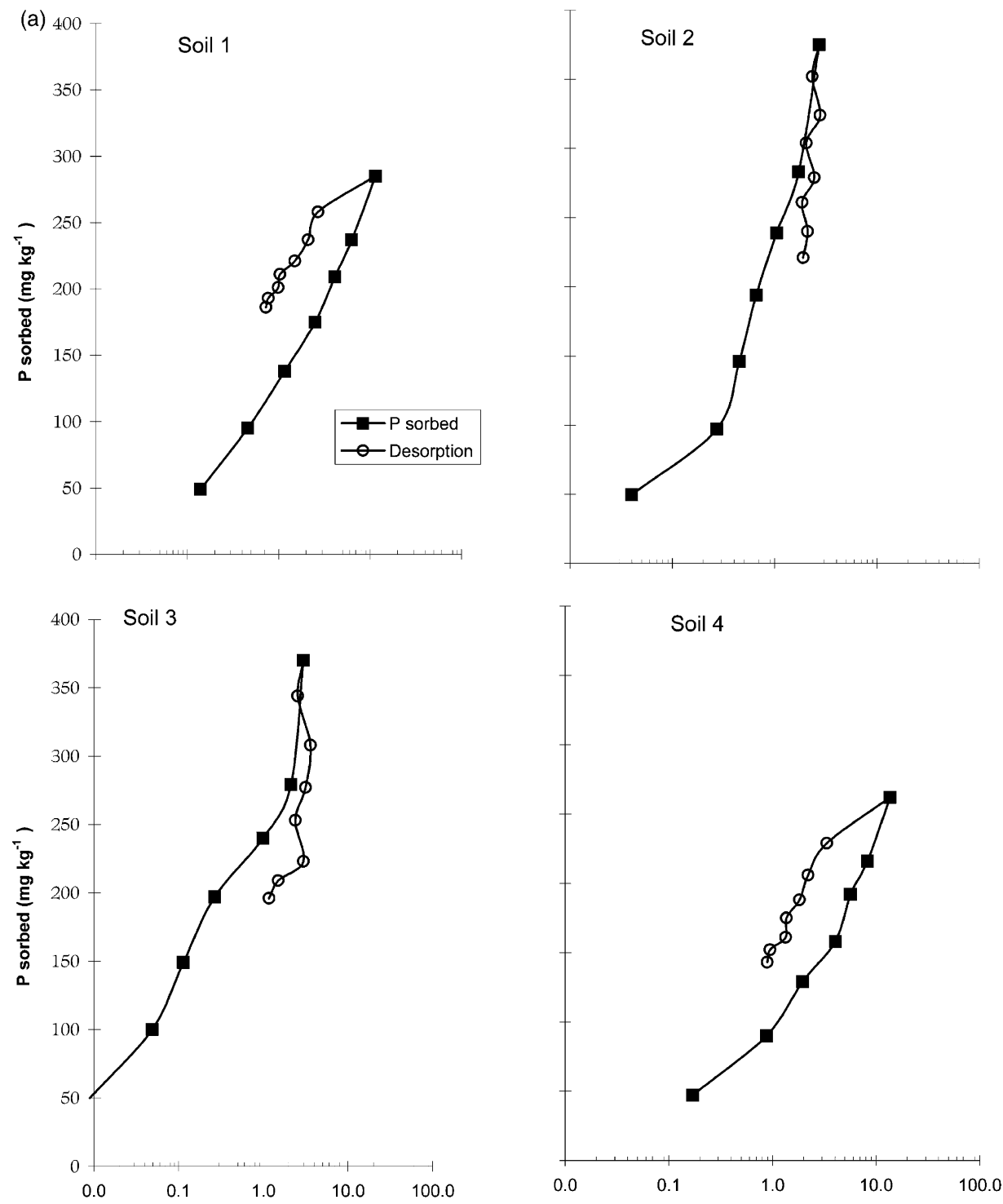

Equilibrium $P$ concentration $\left(\mathrm{mg} \mathrm{L}^{-1}\right)$

Equilibrium $P$ concentration $\left(\mathrm{mg} \mathrm{L}^{-1}\right)$

Fig. 3. Phosphorus adsorption and desorption isotherms for the seven soils. The sorption curves represent a standard sorption isotherm. The seven points along each desorption curve represent a successive step in the repeated extraction. 

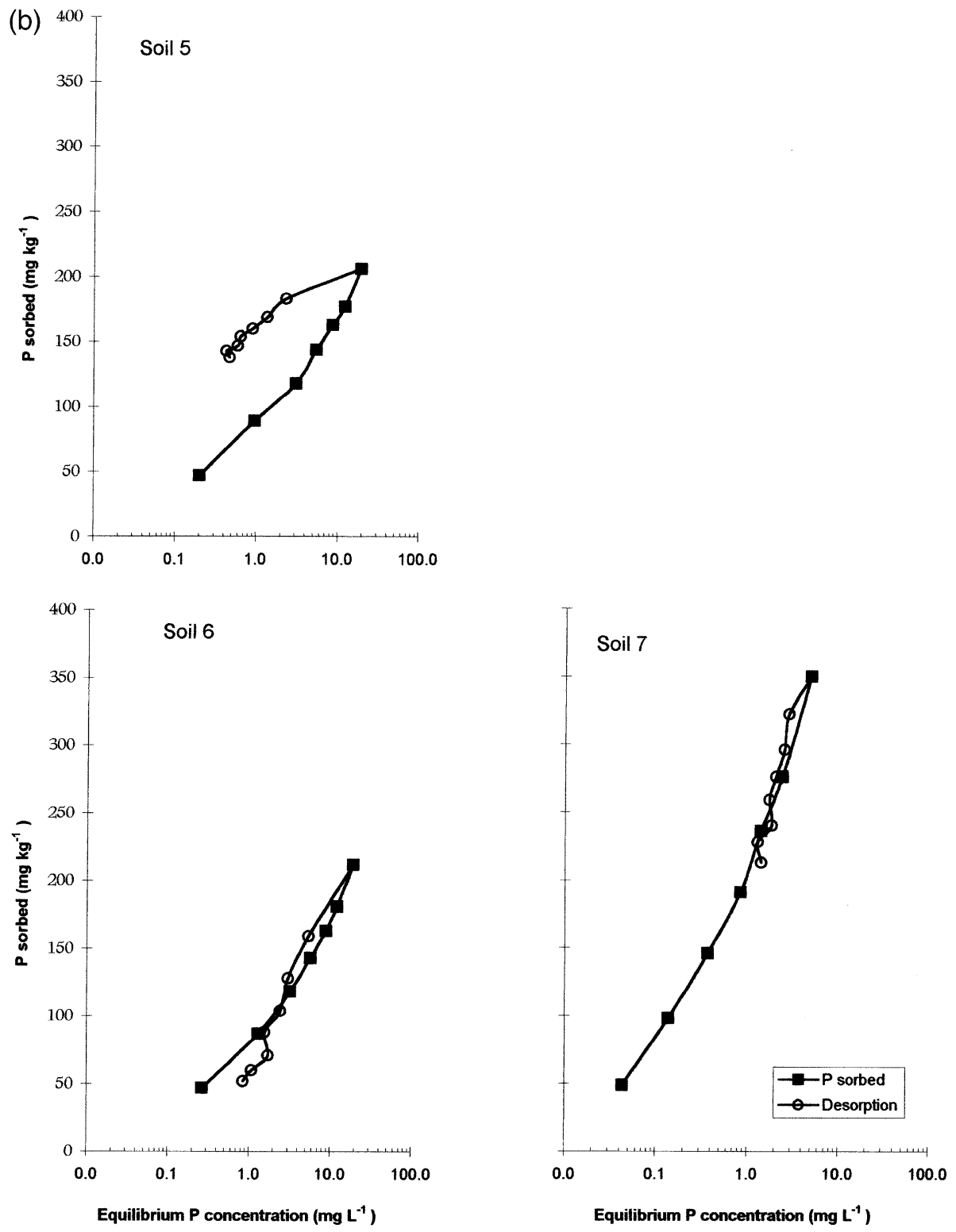

Fig. 3 (continued).

extracted. The relationship between $\mathrm{pH}$ and percentage $\mathrm{P}$ extracted by the Olsen reagent may be explained by the high $\mathrm{HCO}_{3}^{-}$concentration. The high $\mathrm{pH}$ of Olsen's reagent increases the negative charge of the soil, thereby competing with phosphate ions at ligand exchange sites, resulting in release of $\mathrm{P}$ from soils (Hingston et al., 1972). 
Table 5

Bray 1 and Olsen extractable $\mathrm{P}$ in the soils after 1 week of incubation with $40 \mathrm{mg} \mathrm{P} \mathrm{kg}{ }^{-1} \mathrm{soil}^{\text {. }}$ Values reported are net amounts of $\mathrm{P}$ extracted from soils

\begin{tabular}{lcccc}
\hline Soil no. & $\begin{array}{l}\text { Extraction 1 } \\
\left(\mathrm{mg} \mathrm{kg}^{-1}\right)\end{array}$ & $\begin{array}{l}\text { Extraction 2 } \\
\left(\mathrm{mg} \mathrm{kg}^{-1}\right)\end{array}$ & $\begin{array}{l}\text { Sum } \\
\left(\mathrm{mg} \mathrm{kg}^{-1}\right)\end{array}$ & $\begin{array}{l}\text { P recovery in } \\
\text { two extractions }(\%)\end{array}$ \\
\hline Bray 1 & & & & \\
1 & 9.47 & 5.27 & 15.2 & 38 \\
2 & 4.94 & 4.20 & 9.14 & 23 \\
3 & 5.10 & 3.85 & 8.95 & 22 \\
4 & 8.47 & 2.87 & 11.8 & 28 \\
5 & 5.86 & 1.88 & 7.74 & 19 \\
6 & 14.70 & 1.19 & 15.9 & 40 \\
7 & 3.41 & 2.74 & 6.15 & 15 \\
& & & & \\
Olsen & & & & 68 \\
1 & 21.00 & 6.10 & 27.1 & 112 \\
2 & 28.80 & 15.8 & 44.6 & 21 \\
3 & 6.43 & 1.79 & 8.22 & 55 \\
4 & 16.80 & 4.98 & 21.8 & 41 \\
5 & 12.60 & 3.54 & 16.1 & 72 \\
6 & 24.30 & 4.60 & 28.9 & 24 \\
7 & 5.86 & 3.56 & 9.42 & \\
\hline
\end{tabular}

In contrast, there was no relationship between percentage $\mathrm{P}$ extracted by Bray 1 and $\mathrm{pH}(r=0.009)$, indicating that $\mathrm{pH}$ was not the main factor controlling the extraction by the acid reagent. Also, the Olsen reagent extracted more $\mathrm{P}$ $(21-112 \%)$ than the Bray $1(15-40 \%)$ at the end of two successive extractions.

\subsection{Relationship between $\mathrm{pH}$ in various salts and phosphorus retention by soils}

The $\mathrm{pH}$ in $1 \mathrm{M} \mathrm{NaF}$ was between 8.7 and 10.0 , showing that $\mathrm{F}^{-}$replaces $\mathrm{OH}^{-}$from soil minerals (Perrot et al., 1976a; Bolland et al., 1996). In 0.5 M $\mathrm{NaHCO}_{3}$, soil $\mathrm{pH}$ was fairly constant at 8.6-8.8 (Table 2). The $\mathrm{pH}$ in $\mathrm{NaF}$ correlated positively with Langmuir $\mathrm{b}\left(r=0.935^{* *}\right)$ and $\mathrm{Fe}_{\mathrm{d}}\left(r=0.819^{*}\right)$ (Table 4) indicating that both $\mathrm{F}^{-}$and phosphate adsorption related to surface $\mathrm{OH}^{-}$groups mainly of $\mathrm{Fe}$ oxides. Rapid laboratory and field tests of soil $\mathrm{pH}$ in $\mathrm{NaF}$ have been used to detect allophanic and aluminium-rich soils (Perrot et al., 1976b). These results are in agreement with those reported by Bolland et al. (1996) for Australian soils and the test merits further evaluation in soils of the humid forest zone of West Africa.

\section{Conclusions}

Based on the study, two categories of soils are presented: soils 1, 4, 5 and 6 are low $\mathrm{P}$-adsorbing soils and require low rates of $\mathrm{P}$ additions whereas soils 2,3 
and 7 will need relatively large amounts of P. In the second group of soils, the key process in their $\mathrm{P}$ management is the amount of $\mathrm{P}$ released and made available for plant uptake.

Soil 2 with the highest $\mathrm{P}$ adsorption capacity had all the adsorbed $\mathrm{P}$ released within two extractions by Olsen reagent which suggests that the critical P level of such a soil will be low despite its high $\mathrm{P}$ adsorption capacity. The residual $\mathrm{P}$ effects may be stronger on this soil. On the other hand, our experience with soil 7 shows that residual $\mathrm{P}$ effects of applied $\mathrm{P}$ in the field decreased tremendously after the first year of application. Hence, frequent, small rates of $\mathrm{P}$ may be beneficial for rice farmers on soil 7. Addition of organic matter or leaving crop residues in the field to decompose may reduce $\mathrm{P}$ adsorption and increase $\mathrm{P}$ availability (Easterwood and Sartain, 1990). Breeding for rice varieties that are adapted to low soil $\mathrm{P}$ conditions is currently being pursued by the West Africa Rice Development Association (WARDA). The use of such cultivars along with $\mathrm{P}$ management practices is seen as promising for the sustainable increase in rice productivity in the humid zone of West Africa (Sahrawat et al., 2000).

\section{Acknowledgements}

M.K. Abekoe thanks the West Africa Rice Development Association (WARDA) for the award of a Visiting Scientist fellowship and support of the study. The help offered by the technical staff of the Soil Science Division of WARDA in the course of the analytical work is very much appreciated.

\section{References}

Adetunji, M.T., 1997. Phosphorus sorption capacity of low activity clay soils of South Western Nigeria and its usefulness of P requirement of rice. Nutrient Cycl. Agroecosyst. 47, 181-188.

Bolland, M.D.A., Gilkes, R.J., Brennan, R.F., Allen, D.G., 1996. Comparison of seven phosphorus sorption indices. Aust. J. Soil Res. 34, 81-89.

Dev, G., Saggar, S.N., Vig, A.C., 1990. Effect of extended rice-wheat sequence on available phosphorus status in soils. In: Stewart, J.W.B (Ed.), Soil Quality in Semi-arid Agriculture, vol. II, pp. 108-115.

Easterwood, G.W., Sartain, J.B., 1990. Clover residue effectiveness in reducing orthophosphate sorption on ferric hydroxide coated soil. Soil Sci. Soc. Am. J. 54, 1345-1350.

FAO, 1988. FAO/UNESCO Soil Map of the world. Revised Legend. World Resources Report 60. Food and Agriculture Organization of the United Nations, Rome.

Fox, R.L., Kamprath, E.J., 1970. Phosphate sorption isotherm for evaluating the phosphate requirements of soil. Soil Sci. Soc. Am. Proc. 35, 154-156.

Hingston, F.J., Posner, A.M., Quirk, J.P., 1972. Anion adsorption by goethite and gibbsite: I. Role of the proton in determining adsorption envelopes. J. Soil Sci. 23, 177-192.

Holford, I.C.R., 1979. Evaluation of soil phosphate buffering indices. Aust. J. Soil Res. 17, 495-504. 
Juo, A.S.R., Fox, R.L., 1977. Phosphate sorption characteristics of some benchmark soils of West Africa. Soil Sci. 124, 370-376.

McKeague, J.A., 1978. Manual on Soil Sampling and Methods of Analysis. 2nd edn. Can. Soc. Soil Sci., Ottawa, Canada.

Mehra, O.P., Jackson, M.L., 1960. Iron oxide removal from soils and clays by dithionite-citrate system buffered with sodium bicarbonate. 7th National Conference on Clays and Clay Minerals, p. 317.

Mokwunye, A.U., Chien, S.H., Rhodes, E., 1986. Phosphate reactions with tropical African soils. In: Mokwunye, A.U., Vlek, P.L.G. (Eds.), Management of Nitrogen and Phosphorus in Sub-Saharan Africa. Martinus Nijhoff Publishers, Netherlands, pp. 253-281.

Narteh, L.T., Sahrawat, K.L., 1999. Influence of flooding on electrochemical and chemical properties of West African soils. Geoderma 87, 179-207.

Olsen, S.R., Sommers, L.E., 1982. Phosphorus. In: Page, A.L., Miller, R.H., Keeney, D.R. (Eds.), Methods of Soil Analysis, Part 2. Chemical and Mineralogical Properties. Am. Soc. Agron., Madison, WI, pp. 403-430.

Owusu-Bennoah, E., Acquaye, D.K., 1989. Phosphate sorption characteristics of selected major Ghanaian soils. Soil Sci. 48, 114-123.

Owusu-Bennoah, E., Szilas, C., Hansen, H.C.B., Borggaard, O.K., 1997. Phosphate sorption in relation to aluminum and iron oxides of Oxisols from Ghana. Commun. Soil Sci. Plant Anal. 28 (9-10), 685-697.

Perrot, K.W., Smith, B.F.L., Inkson, R.H.E., 1976a. The reaction of fluoride with soils and soil minerals. J. Soil Sci. 27, 58-67.

Perrot, K.W., Smith, B.F.L., Mitchel, B.D., 1976b. Effect of $\mathrm{pH}$ on the reaction of sodium fluoride with hydrous oxides of silicon, aluminium and iron and with poorly ordered aluminosilicates. J. Soil Sci. 27, 348-356.

Sahrawat, K.L., Jones, M.P., Diatta, S., 1995. Response of upland rice to phosphorus in an Ultisol in the humid forest zone of West Africa. Fertil. Res. 41, 11-17.

Sahrawat, K.L., Jones, M.P., Diatta, S., 1997a. Direct and residual fertilizer phosphorus effects on yield and phosphorus efficiency of upland rice in an Ultisol. Nutrient Cycl. Agroecosyst. 48, 209-215.

Sahrawat, K.L., Jones, M.P., Diatta, S., 1997b. Extractable phosphorus and rice yield in an Ultisol of the humid forest in West Africa. Commun. Soil Sci. Plant Anal. 28, 711-716.

Sahrawat, K.L., Jones, M.P., Diatta, S., 1998. Plant phosphorus and rice yield in an Ultisol of the humid forest zone in West Africa. Commun. Soil Sci. Plant Anal. 29, 997-1005.

Sahrawat, K.L., Jones, M.P., Diatta, S., 2000. The role of tolerant genotypes and plant nutrients in the management of acid soil infertility in upland rice. Management and Conservation of Tropical Acid Soils for Sustainable Crop Production. Proceedings of Consultants Meeting organized by the Joint FAO/IAEA Division of Nuclear Techniques in Food and Agriculture Production and held in Vienna, 1-3 March, 1999. IAEA-TECDOC, vol. 1159, International Atomic Energy Agency (IAEA), Vienna, Austria, pp. 29-43.

Sanchez, P.A., Salinas, J.G., 1981. Low input technology for managing Oxisols and Ultisols in tropical America. Adv. Agron. 34, 280-406.

Tiessen, H., Abekoe, M.K., Salcedo, I.H., Owusu-Bennoah, E., 1993. Reversibility of phosphorus sorption by ferruginous nodules. Plant Soil 153, 113-124.

Warren, G.P., 1992. Fertilizer Phosphorus. Sorption and Residual Value in Tropical African soils. NRI Bull., vol. 37, Natural Resources Institute, Chatham, UK, p. 91. 